\title{
The Minoan 'Palace-Temple' Reconsidered: A Critical Assessment of the Spatial Concentration of Political, Religious and Economic Power in Bronze Age Crete
}

\author{
Ilse Schoep \\ Department of Archaeology, Catholic University of Leuven, PB 3313, 3000 Leuven Belgium \\ E-mail: Ilse.Schoep@arts.kuleuven.be
}

\begin{abstract}
Although aspects of Arthur Evan' vision of Minoan society have undergone modification during the course of the 20th century, his basic interpretation of the monumental building complex with courts at Knossos as a Palace-Temple, or the residence of both a political and religious authority, remains the dominant paradigm in Minoan archaeology. When set within the context of other contemporary Bronze Age societies in the eastern Mediterranean, however, Evans' model of a priest-king who resided in a Palace-Temple is actually highly unusual and anomalous. Indeed, it will be argued that the Palace-Temple model was entirely invented by Evans as a distinctive, formative and intermediate stage between the Oriental Temple, which was the model then current in the Near East at the time of his writing, and what might be termed European kingship. The perception that Cretan culture and society was essentially European (and thus different from the East) formed a cornerstone of Evans' vision and its enduring popularity goes some way to explaining why the intellectual and empirical origins of Evans' Palace-Temple model have not previously been critically reassessed.
\end{abstract}

Keywords: kingship, Minoan palace, political authority, social organization, temples

This comparatively small island, left on one side today by all the main lines of Mediterranean intercourse, was at once the starting point and the earliest stage in the highway of European civilization (Evans 1921: 24).

\section{Introduction}

Ever since their discovery early in the twentieth century, the monumental building complexes with courts, known as palaces and widely considered to embody all that is sophisticated of Bronze Age Cretan 'civilization', have dominated and directed the development of the discipline of Minoan archaeology. They are, to quote Warren (1985: 94): 'one of the best sources of information about the social structure and culture of

(C) The Fund for Mediterranean Archaeology/Equinox Publishing Ltd., 2010
Bronze Age Crete'. This generally accepted view of the palaces, as barometers of social complexity and as pars pro toto representations of Minoan society, finds its origins in Evans' view that the palaces were the residence of the highest political and religious authority within a hierarchically structured society (Evans 1921: 3-4). Evans' Palace-Temple model remains profoundly influential, albeit with minor tweaks and shifts in emphasis, most notably an increased emphasis on the political and economic over the religious and ceremonial (Renfrew 1972; Halstead 1981, 1988; Halstead and O'Shea 1982; Branigan 1987; 1988; Cherry 1986). This was triggered by the decipherment of Linear B in 1952 and the insights this brought into the economy of the LM III Minoan and the Mycenaean 
palaces (Finley 1957: 135) and is reflected in the general convention now to omit mention of the original '-Temple' component and refer solely to the court buildings and the institution they housed as 'palaces'. The dominance of the Palace-Temple model can be measured in its central position in didactic handbooks or syntheses (Dickinson 1994a; Manning 2008; Treuil et al. 2008: 229) and other more popularizing treatments of Minoan Archaeology (Warren 1975; 1985; Pelon 1997; Runnels and Murray 2001; Betancourt 2007), which together, through the dialectical relationship between specialist and more popular media (Moser 2001), play a profound role in the formation of public opinion. A notable exception is a recent handbook by Preziosi and Hitchcock (2000), which (refreshingly) draws attention to the uncertainties surrounding the Palace-Temple model, noting that: 'There is no solid evidence that these [the Palaces] were the residences-permanent or temporary-of queens, kings, or priests, or other political or religious functionaries' (Preziosi and Hitchcock 2000: 64); and 'The fact of the matter is that we do not know for certain just how the great central building compounds were actually used' (Preziosi and Hitchcock 2000: 89).

Critical assessments of the Minoan PalaceTemple model and its conceptual and theoretical basis have, however, significantly increased in incidence over the last two decades (Bintliff 1984; Farnoux 1995; MacGillivray 2001; Hamilakis 2002b; Papadopoulos 2005; Darcque et al. 2006; Hamilakis and Momigliano 2006; Gere 2009). Doubts have been expressed about the supposed palatial control over trade (Branigan 1989; Warren 1985: 101), the scope and redistributive nature of the palace economy (Halstead 1992; 2004), the storage capacity of the palaces (Strasser 1997), and the extent to which they may have controlled the production of the fineware ceramics that they consumed (Day and Wilson 1998). Such work has played an important role in drawing attention to the role played by powerful agents outside the palace and in dismantling the assumption of palatial economic monopoly (Schoep 2002; 2004; 2006).

From this critical movement several alternative power models for Minoan society have emerged. Hamilakis (2002a) has suggested replacing the traditional model of a hierarchical class system with one based on factions and factional competition, thus introducing social tension and competition into a world previously inhabited by well-natured and obedient palatial followers. His location of the most important faction in the palace (Hamilakis 2002a: 188) actually makes this model far less drastic than has been claimed by some (Knappett 2009). Re-interrogation of the archaeological record has revealed that a considerable amount of social competition was taking place outside the palaces in settlements and cemeteries (Hamilakis 2002a; Schoep 2002; Adams 2006) and that political power, rather than being centralized and permanent, may have been fluid and shifting, and more fragmented, short-lived and contested than previously assumed (Hamilakis 2002a: 193; Schoep 2002: 106-107).

What has not thus far been critically examined, however, is the core assumption underscoring Evans' Palace-Temple model and its subsequent reception, that sacred power and political power might be spatially concentrated within a single building. Thus, to quote Warren (1985: 94): 'Great power was concentrated in these elaborate structures: both the secular and the religious authorities of Minoan societies lived in them... the Palace rulers probably had considerable control over agriculture in the region around the Palace and also over Crete's rich foreign trade'. Hood (1995) has described the palaces as the residences of gods and men. Halstead (1998) memorably described them as a combination of Buckingham Palace, Whitehall, Westminster Abbey and Wembley Stadium. Platon (1983: 276) emphasised the theocratic nature of society and assumed that the royal family belonged to the priesthood. MacGillivray (1994: 55) suggested that the first 'palace' served 
not only as 'a place of worship and as storehouse for wealth-rather like an early temple', but also 'as the dwelling of the ruling family-like the contemporary palaces in the Near East'.

In the first part of this paper, the origins and efficacy of Evans' Palace-Temple model will be briefly explored with specific reference to what was then and is now known about contemporary Bronze Age political cultures in Anatolia, the Near East and Egypt. This comparison not only has the value of clarifying and contextualizing the strands of Evans' thinking that were woven into his Palace-Temple model, but also provides the basis for a reassessment of the Cretan evidence. Drawing on the wealth of data now available for Crete, the second part of this paper will explore the efficacy of an alternative model of power, more specifically based on other Bronze Age societies in the eastern Mediterranean, where Evans' hybridized elements of Palace and Temple are split and where different, spatially separated domains of power are understood to exist.

\section{Evans, the Priest-King and the Palace-Temple}

There are several reasons why Evans chose to interpret the large court building at Knossos as a Palace-Temple and the residence of a PriestKing. First and foremost was his specific reading of the evidence as it emerged from the soil of the Kephala Hill at Knossos. From the first season of excavation in 1900, the highlight of which was the discovery of the 'earliest throne in Europe', Evans interpreted the large and predominantly Late Bronze Age building complex at Knossos as a palace-that is, as the seat of power and residence of a dynasty of kings (Evans 1921; Farnoux 1995; Hamilakis 2002b). An interpretation of these buildings simply as palaces, however, would have left Evans with a problem as this would have left Minoan Crete curiously lacking the sorts of temples that were already known from Egypt and the Near East.
The solution was to define the court building at Knossos as both a palace and a temple. Justifying the religious character of this building and of the ruler inhabiting it presented no great difficulties for Evans, as the evidence for cult was overwhelming. The discovery of the Grandstand Fresco with its tripartite shrine (MacGillivray 2001: 192, 207), the location of which Evans identified with the east façade of the west wing, was seen as confirmation of the identification of the court building as a 'Palace-Temple' (MacGillivray 2001: 192). Having thus established the sacred character of the building, Evans then sought evidence to support the idea that the building functioned also as the residence of a priest-king in a series of fresco fragments from a male figure with naked torso and a feathered crown with lilies (MacGillivray 2001: 204). The fragments were reconstructed as the best known and perhaps most iconic of modern Minoan frescoes, 'the Prince of the Lilies' or 'the Priest-King'. Although Gilliéron's reconstruction has been criticized by some scholars (Coulomb 1979; Niemeier 1987), others have jumped to its rescue. Recently, Shaw, after studying the actual fresco remains in the Heraklion Museum, concluded that there were traces of long hair to the right of the head and that the figure was facing left and not right as had been suggested by Coulomb and Niemeier (Shaw 2004; Marinatos 2007). Nonetheless, the position of the hair neither justifies the interpretation of this figure as the Priest-King, nor proves that the feather crown belongs to the male figure. Recently, a couple of hitherto unknown sketches by Evans from the Ashmolean Museum demonstrate the degree to which Evans was involved in the creation of the Priest-King (Sherratt 2000; 2005). The reason for his special interest in this regard is not hard to divine. As Farnoux (1995: 330) notes, the Priest-King was critical to the acceptance of Evans' theories as it explained the otherwise puzzling absence of any convincing evidence for a monarch: 
D'une certaine manière, le roi minoen ne peut exister que sous la forme d'un prêtre parce qu'il n'y a pas d'autres évidences de la royauté. Evans a besoin de l'équipement cultuel découvert dans le palais de Cnossos pour affirmer l'existence d'une royauté dans la Crète minoenne.

In this way, as MacGillivray (2001: 204) notes, the Priest-King was 'born of separated limbs united to satisfy Evans' need for an earthly authority at Knossos'.

But where did the idea for a Minoan PriestKing come from? Evans' cultural and intellectual background undoubtedly influenced his interpretations, not just contemporary Victorian and Edwardian society and its political structures ('British monarchy'), but also the intellectual milieu within which he was educated and employed (MacGillivray 2001: 11-27). In the case of the Priest-King he was drawing on ideas expressed by Frazer, who considered the Priest-King as a stage in political development between the Priest-Magician and the Priest-God (Farnoux 1995: 327). Although Evans seems to have been less interested than some of his contemporaries in explicitly detailing his vision and credo regarding human socio-political development and the emergence of modern European society, it would seem that he saw the Minoan Priest-King and Palace-Temple as an intermediate stage between the Oriental Temple-State, which was the then dominant model for Near Eastern political organization (see Robertson 1995: 450-51 for discussion and references), and what might be termed European monarchy (see also Farnoux 1995: 328).

\section{Creto-centrism and Cretan Otherness}

It is surely rather the positive anomaly of Crete which requires explanation (Lewthwaite 1983: 179).

In order to achieve this objective, Evans needed to establish Minoan civilization as a true rival to the Mesopotamian and Egyptian civilizations
(Papadopoulos 2005), and one where elements of Oriental civilizations were transformed into something recognizably different, dynamic and, crucially, European in character (Hamilakis 2002b; Papadopoulos 2005: 109; Hamilakis and Momigliano 2006). Evans drew on a variety of sources for inspiration and, as first pointed out by Bennett (1961-62), this borrowing was eclectic, resulting in a interpretative framework that, although not always as coherent or consistent as it might at first appear (McEnroe 1995; Papadopoulos 2005; Gere 2009: 5), produced an end-product that was reassuringly familiar to Europeans and quickly became universally accepted (Farnoux 1995; Sherratt 2005).

Evans was among the first to give Europe a prehistoric identity (Papadopoulos 2005: 107) and went to great lengths to emphasize the European character of Cretan Bronze Age society, both through extensive use of Greek mythology (MacGillivray 2001; Momigliano 2006) and through emotive reconstructions of the architecture of the palace (Hitchcock and Koudounaris 2002; Papadopoulos 2005; Gere 2009) and Minoan material culture. The transformation of the court building on the Kephala hill into the 'Palace of Minos' enhanced this sense of familiarity (Papadopoulos 2005: 110-22). Some areas of the palace were restored in the architectural fashion of the day: the Throne Room and the North-West Lustral Basin forming some of the finest examples of Art Nouveau and Art Deco architecture in modern Greece (Papadopoulos 2005: 119). The resemblances between Art Nouveau and Minoan material culture are the result of a dialectic interaction between modernist artists, archaeologists and the restorers (and fakers) of Minoan material culture (Farnoux 1993; Blakholmer 2006).

The attractive colours and naturalism used in Minoan material culture have also played a major role in the perpetuation of Minoan myth and have delighted generations of Minoan archaeologists and art historians. The former is universally deemed worthy of the designation 
'art' (Hutchinson 1962: 123; Higgins 1967; Hood 1978) and its European character has been consistently emphasized (Charbonneaux 1929: 5; Hutchinson 1962: 123; Higgins 1967: 17; Warren 1975: 41-42). This is important because in European modernity, 'art' was considered a palpable measure and mark of cognitive advancement (or decline) on the scale of the individual or of an entire race (Preziosi 2002: 36). Through the material culture of a society, the character, 'spirit', 'mentality' or 'soul', and even ethnic identity and cognitive capacity, of a nation or people could be (re)discovered (Preziosi 2002: 32). Similarities between many aspects, from art to plumbing, played a role in perpetuating a sense of familiarity with the 'Minoans'.

Evans's views should be seen in the context of both the general obsession of western Europe with ancient Greece, and Evans' personal involvement in the eastern question and his colonial politics (McEnroe 2002: 63; Papadopoulos 2005: 91). Underscoring the views of Evans and his contemporaries was a strongly anti-oriental and even, according to some, racist undertone emphasising Western superiority (McEnroe 2002: 64, 69; Papadopoulos 2005: 126; Gere 2009: 112; Evans 2008 [1877]). Essentially he saw Minoan society as a mirror image of European colonial and imperial capitalism in the 19th and the 20th centuries (Hamilakis and Momigliano 2006). As Crete was the cradle of European civilization, so England was, or would be, the culmination of European civilization (McEnroe 2002: 69). By proclaiming Crete as the 'cradle of European civilisation' (Evans 1921: 24), he substituted the 'Greeks' for the 'Minoans' (Momigliano 2006: 77). This Creto-centric view also underpins his views of the Mycenaeans, who were characterized in opposition to the Minoans (Preziosi and Hitchcock 2000: 9)-and sometimes still are (Warren 1975: 41-42; Runnels and Murray 2001). In this way, Minoan Crete became one of the touchstones by which Westerners fixed the boundary between the static East and the progressive West, a boundary which in the view of many Europeans excluded modern Crete (McEnroe 2002: 64).

The natural corollary of Evans' desire to familiarize and connect his European audience with Minoan Crete, or what might be termed 'Creto-centrism', was the need to emphasise Crete's uniqueness from other contemporary Bronze Age societies in the eastern Mediterranean (MacGillivray 2001; Papadopoulos 2005). Thus, for example, when comparing the Cretan linear script with the tablets from Babylon, Evans asserts that in Crete 'the letters themselves... are of a free, upright European character' (in contrast with the Arabs' cursive script and the Assyrians' cuneiform letters [MacGillivray 2001: 195-96]). The undeniable links between Crete and the cultures of the eastern Mediterranean, however, could not be completely suppressed (Evans 1921: 14-21). Evans, however, recast them as part of a process by which ex oriente lux was transformed by the entrepreneurial Minoans into the free European spirit of capital, commerce and trade (Hamilakis and Momigliano 2006: 27). Thus:

Insular, but not isolated, it was thus able to develop a civilization of its own on native lines and to accept suggestions from the Egyptian or the Asiatic side without itself being dominated by foreign conventionalism (Evans 1921: 25).

Its enterprising inhabitants continually absorbed and assimilated Egyptian forms and ideas, developing them on independent lines. They took what they wanted, nothing more, and were neither artistically nor politically enslaved (Evans 1921: 19).

A similar view of the inventiveness of the Cretans, perceived in terms of their capacity to transform foreign influences into something that was essentially different from Egypt and Mesopotamia (and thus European), is also to be found in other publications (Charbonneaux 1929: 5; Hutchinson 1962: 123; Higgins 1967: 
17; Warren 1975: 41-42), some of them quite recent:

The art found in the Palaces reflects a vitality and humanism that distinguishes Crete from contemporaneous societies such as Egypt and Assyria. The origin of the European tradition of humanism and individualism is generally attributed to the Greeks, but there is a sense in which Minoan culture can be considered the first example of a distinctively European tradition (Warren 1985: 94).

By introducing the Minoan Palace-Temple model, Evans made Crete different from Egypt where the royal and priestly were kept somewhat apart' (Evans 1921: 3). Instead, Evans draws heavily on analogies with Anatolia (also from later periods), not only in arguing for the existence of a Minoan priest-king with a divine element, but also numerous Anatolian influences in Minoan religion (Evans 1921: 3-7):

The most ancient features in the Cretan religion find, in fact, their closest analogies on the Anatolian side, where was another Ida and another Diktê. There we recognise under manifold appellations the same Great Mother with a male satellite who may stand to her in various relationships (Evans 1921: 6).

Running as an undercurrent through his discussion is the belief that, although there were connexions with Anatolia (Evans 1921: 14) and Egypt, perhaps even in the form of an exodus of an older race (Evans 1921: 16-17), there is little evidence for direct relations with the easternmost Mediterranean shores before the close of the Middle Minoan Age (Evans 1921: 15). This becomes especially clear in his discussion of the origins of Minoan iconography in the fourth volume of Palace of Minos, where he argues that there was no direct Semitic influence, but instead traces influences (e.g. dove cult) to Cyprus and/or Anatolia from where they spread east and west, thus dispensing with what he calls the 'Mirage orientale' (Evans 1935:406). Despite his pursuit of analogies with an Anatolian divine ruler, Evans nevertheless was keen also to stress differences, such as his conclusion that in the Minoan model the kingly aspect was more to the fore than in Anatolia (Evans 1921: 5). In this way Evans created a very specific type of kingship for Crete, with its own particular regalia and insignia (Farnoux 1995: 329). Overall, Evans' wider aim seems to have been to establish the Minoan Priest-King and Palace-Temple as an intermediate stage between the Temple-State, which was the dominant social and political model for the Oriental civilization in Evans' day (Robertson 1995: 450-51), and a more recognizably European form of monarchy.

Evans' vision of Minoan religion serves as a further illustration of his belief in Crete's otherness from other Oriental civilizations and its European credentials. Initially, he believed Minoan religion to be based on the cult of pillars and trees, and thus aniconic (Evans 1901; MacGillivray 2001: 152, 236); but after the start of his excavations at Knossos, he proposed a universal Mother Goddess, attended by a dying and rising male god (Gere 2009: 123-24), who symbolized the agricultural cycle and provided a divine basis for primitive kingship. Evidence for the Mother Goddess cult was sought in the 'Mother of the Mountain sealing' and the faience Snake Goddess in the Temple Repositories (MacGillivray 2001: 223-24; Lapatin 2002). Although a comparison between the latter and the Egyptian goddess Hathor would have been more straightforward (because of the associated group of cow and calf (MacGillivray 2001: 223-24), Evans opted for an interpretation as Mother Goddess and for close parallels with the Anatolian Mother Goddess (Evans 1921: 6). Evans' claim of a monotheistic belief system is so unusual in the context of the Bronze Age that it needs some explanation. Dickinson (1994b), and recently also Morris (2006) and Gere (2009), evoked Evans' socio-cultural and personal background to explain his vision of Minoan religion as based upon a single female fertility-goddess. Today, although a case can be 
made for a polytheistic pantheon with male and female deities, some of which survive in the Linear B tablets (Marinatos 1993), a monotheistic belief system still finds acceptance in some quarters (Gesell 1983; Driessen 2001).

Following the publication of The Emergence of Civilisation (Renfrew 1972), Creto-centrism and a general belief in Cretan 'otherness' found itself reinforced by a paradigm shift in the explanation of the origins of Cretan 'civilization' away from external influences and towards indigenous processes (Renfrew 1972; Warren 1987; Branigan 1988; for an exception, see Watrous 1987). According to Renfrew (1972: $\mathrm{xxv}$ ), although important contacts clearly existed between the early Aegean and the Orient, these do not in themselves provide a satisfactory explanation for the emergence of the first civilization in Europe. Rather, the origins of the Minoan palaces should be sought in the Early Minoan period and should be understood as the outcome of an indigenous development that set Crete apart from the rest of the Mediterranean.

In Crete, even during the third millennium B.C., and thus before the emergence of the palace civilisation, the finds are all instantly recognisable as 'Minoan' (Renfrew 1972: 47).

This approach not only stressed the indigenous character of developments on the island, but also provided the western nation-state with European origins (Hamilakis 2002b). The identification of the Minoan palaces as centres of states (Cherry 1984; 1986) gave a new twist to Crete's otherness, in that it appeared to be the only place in the Aegean to reach this level of 'complexity' as early as the Middle Bronze Age (Cherry 1984; Warren 1985; Knappett 1999: 620; Manning 2008: 105-106; Broodbank 2000). The perception of Crete's position as unique consequently inspired numerous studies to try to account for this uniqueness and, more specifically, the emergence of the Minoan palaces (Halstead 1981; Halstead and O'Shea 1983; Lewthwaite 1983; Warren 1987; Manning 1994: 179, 242;
Branigan 1989). Lewthwaite (1983: 179) noted that, rather than the absence of a palace in other geographical areas, 'it is surely rather the positive anomaly of Crete which requires explanation'.

In this way, all such explanations have, following Evans, accepted Cretan otherness as an ancient reality. But was Crete really a unique outcome, a product perhaps of its insular position, and hence fundamentally different from contemporary Bronze Age societies? Or is this reading of the data a more recent construct, which might be termed 'Creto-centrism', where the pivotal role of Crete in grand narratives for the origins of European modernity have granted it special status and unique treatment within wider Mediterranean prehistory? In the following section, an alternative proposition is explored-namely, that the uniqueness of Crete, enshrined in the Palace-Temple model, is essentially a modern construct, originating with Evans, and that a very different picture emerges once power dynamics on Crete are situated back within the broader context of the eastern Mediterranean.

\section{The Traditional Minoan Palace Model in its Wider Geographical Context}

While phenomena such as palaces, Priest-Kings, palatial crafts and palatial administration find obvious parallels in the contemporary societies of the East, it is Evans' interpretation of the court buildings as Palace-Temples-that is, as residences for a political and religious authority—-that most clearly sets Crete apart in the wider eastern Mediterranean region (Evans 1935: 960) (Figure 1). In casting around for parallels, Evans claimed to find analogies in the great religious centres of Anatolia, where the royal and sacerdotal abode was one and the same, and the Palace was also a Sanctuary' (Evans 1921: 3-4). It is clear now, however, that in this he was mistaken, as later excavations have shown that the Lower Palace (Garstang 1929: 88) was actually the Great Temple and that the palace 


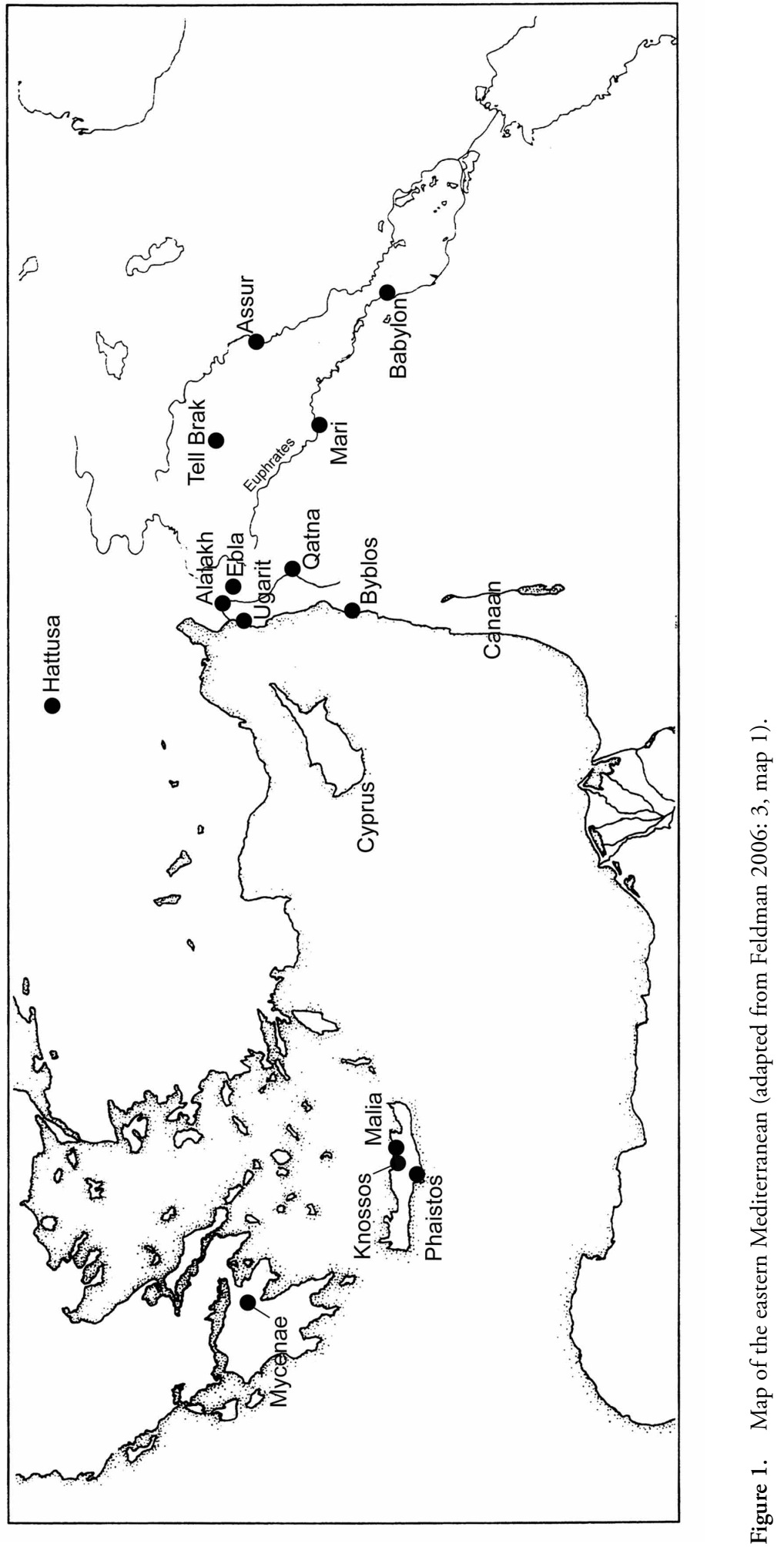

(C) The Fund for Mediterranean Archaeology/Equinox Publishing Ltd., 2010 
was situated elsewhere (Neve 1995). Rather, as the following brief overview will make clear, it is common practice in Bronze Age eastern Mediterranean societies for the main political and religious venues of power, usually referred to as the palace and the temple, to be located in different places in the urban landscape.

In the Near East, where until the 1950s it was thought that the temple was the only seat of authority (for the temple-state paradigm, see Robertson 1995: 450-51), it is now clear that the power of the temple was counterpoised by the power of the palace (Van De Mieroop 1997: 16; Robertson 1995: 450). As Postgate (1992: 109) points out: 'We cannot any longer maintain that because the temple collected commodities and distributed them to its dependants the entire economy operated through "redistribution", or that the priests controlled all agricultural production and commercial activity'. Near Eastern palaces generally consist of storage rooms, kitchens, production areas and living quarters and a main room that served for giving audiences, usually in association with some sort of court (Postgate 1992; Margueron 1995). The main focus of the temple complex is the temple itself, but, just like the palace, it contained magazines and extensive archives. Temples, regarded as the god's house or estate, and palaces were run separately along the lines of a large elite household and thus both could hold property in more than one place and could engage in a variety of productive and commercial activities (Postgate 1992: 114, 137; Robertson 1995: 444). Thus, despite the spatial separation between palace and temple, it is important to stress that the temple was more than a religious institution and that the palace was also an important ceremonial centre (Sallaberger 2007: 270).

Mesopotamian kingship had a military and religious dimension, and an ideology of secular power cannot be separated from religion. At times, however, there was conflict between secular and religious leaders (Van De Mieroop 1997: 33) and the relationship between the secular pal- ace and the religious temples shifted throughout Mesopotamian history (Van de Mieroop 1997: 16, 120).

A similar spatial separation can be found in early third-millennium вс Canaan, where, in a political landscape divided into competing citystates (De Miroschedji 1999: 5), palace and temple were also spatially separated (Ahlström 1995). This also seems to have been the case at Ebla in Syria (Pinnock 2001: 27), where palace and temple seem to have been distinct institutions (Milano 1995: 1223). Contrary to Mesopotamia, the Eblaite king had a low profile and a major role was played by tribal institutions such as the group of 'elders' (ÁBBA-ÁBBA) and the members of leading families with state responsibilities (LUGAL-LUGAL) (Milano 1995: 1221).

The Egyptian pharaoh was a dual personality, both the embodiment of sacred power and a head-of-state fulfilling a terrestrial function within a human world (Traunecker 2002: 145). The cult of divine kingship was given monumental expression in the form of great religious complexes that were in the first place temples for the royal statues with a royal tomb attached to each temple (Trigger et al. 1983: 85). The Egyptian palaces were places of stately representation where the power of kingship was demonstrated both to Egypt's people and to foreign envoys. It was in the palace, however, that the pharaoh assembled his advisors and officials and decided on matters of state and religion. Since the pharaoh's role was to a large degree a religious one, ancient Egyptian palaces also provided the stage for ritual performances connected with the office of kingship (Arnold 2002: 271). It is very important to stress that even in the case of a theocracy, where sacred and political power are combined in a single person, different aspects of this power are associated with different spatial locales (Baines 1995). In Egypt, not only does political and religious power manifest itself in the construction of palaces and temples, but even the religious and the secular had different capitals, which shifted throughout Egypt's 
history (e.g. Thebes and Memphis, Thebes and Karnak). Much of Egyptian political history was driven by tension and strife between the pharaoh and the priests but ultimately the Egyptian temples remained dependent upon the pharaoh (O’Connor 1995: 321-23).

Evans (1921: 3-4) was of the opinion that in the Anatolian centres the royal and the sacerdotal abode was one and the same and the Palace was also a Sanctuary. It is these last conditions that seem to have most nearly corresponded with those of Minoan Crete', but this statement seems to be informed by the blurred relationship between Hittite kingship and state religion (as obvious from the texts), or by one of the more speculative theories existing at a time when Hittite was still undeciphered and a lot of rather exotic ideas were in circulation (Ulf-Dietrich Schoop, pers. comm.). At the time Evans was writing, the palace at Hattusas (Büyükkale) (Figure 2) had not been discovered and the main temple complex in the lower city was mistakenly known as the 'Lower Palace' (Garstang 1929: 89-90). The palace, which was constructed on a rocky elevation (Büyükkale), was discovered later (Neve 1995). Although Hittite temples were administered by their priesthoods, they were under the ultimate control of the king so there was no state-temple dichotomy (Beckman 1995: 540). The Hittite king was, in addition to being a secular ruler, also the chief priest who was appointed by the divine owner of the Land of Khatti; it is impossible to separate the concerns of temples from other state business recorded in records of the royal archives. Interestingly, the archives refer to the palace as 'House of the king' and to the temple as 'house of the god' (Beckman1995: 530).

This brief overview allows two important points to be made. First, the term 'palace' is used in a much looser way in eastern Mediterranean archaeology than in Minoan archaeology. In the Levant and the Near East, 'palace' is not only used for the residence of a monarch (Margueron 1995: 898), but also for other large residences associated with officials or the family of the monarch (Akkermans and Schwartz 2003: 316). In contrast, in New World archaeology the term 'palace' has a more strict meaning: to be a palace, a structure has to be both a residence and a seat of political power, in that it serves some kind of wider public role (Galaty 2008: 428). It would seem that what is called the palace in Minoan scholarship is best compared to the temple in Anatolia, Egypt and Mesopotamia, and that some of the high-profile buildings in the Minoan urban landscape would be termed palaces in the Near East and the New World.

A second point to be made is that even in theocratic societies, such as those of Bronze Age Egypt and Anatolia, there is a spatial separation between palace and temple or the main secular and sacred venues of power. Despite the prominent role played by the Egyptian pharaohs and the Hittite kings in the religious ceremonies that took place in the temples, the palaces were places of stately representation where the power of kingship was demonstrated and where matters of state and religion were decided.

\section{An Alternative Spatial Model of Power for Crete}

The above observations are worth exploring for the Cretan evidence, not just because they represent a set of contemporary and contiguous analogies for Bronze Age power structures, nor simply because Cretan elites interacted with and clearly at times drew inspiration from the elite cultures of the eastern Mediterranean, but more fundamentally because a spatial separation of the main sacred and the secular venues fits the present Minoan dataset better than Evans' highly unusual and now seemingly artificial hybrid palace-temple model. Significantly, the recognition that the main secular and religious venues of power may have been spatially separated does not rule out the existence of a ruler with religious power, but does suggest that, if such a person existed, he/she would most probably not 


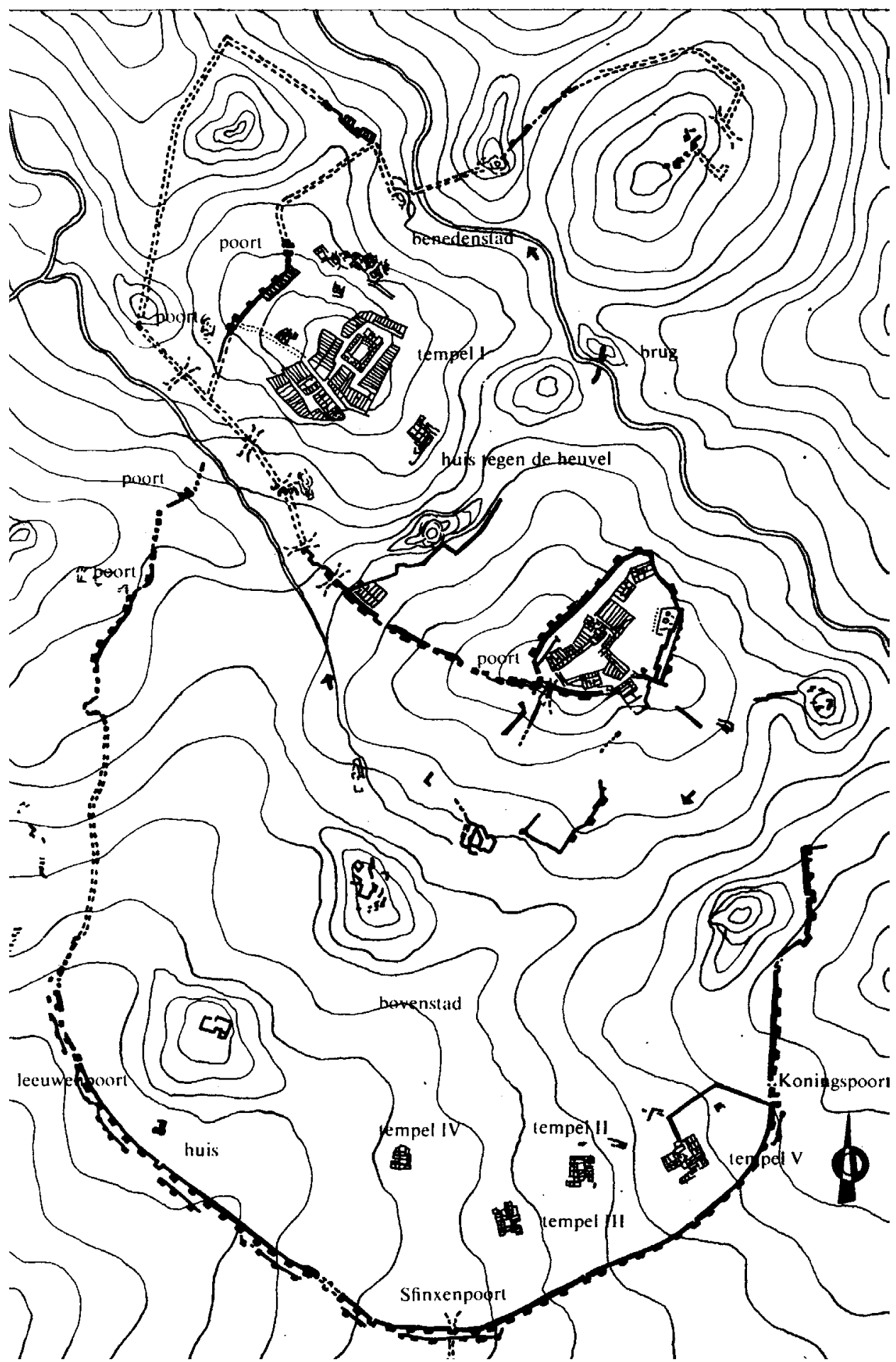

Figure 2. Plan of Hattusas (adapted from P. Neve, Die Ausgrabungen in Bögazköy-Hattusa 1993, Archäologischer Anzeiger 1994: fig. 1). 
have resided in the principal religious building. In this way, this alternative model has the potential to clarify and explain the existence and role of the prominent elite structures known from Minoan towns, as well as the conspicuous presence of elite culture outside the court buildings (Hamilakis 2002; Schoep 2006; 2010).

It should be stressed, however, that-just as in Mesopotamia, Egypt and Anatolia-such spatial separation does not imply a strict conceptual separation between secular and religious power. In addition to palaces containing shrines in the East Mediterranean (see above), there can be no doubt that performances taking place in the Minoan court buildings may have been informed by, had an impact on, or even directed the exercise of political power; and, vice versa, that performance in the more overtly political venues, such as high-profile elite residences, had a religious and ceremonial component to them. In addition, it should be kept in mind that the sacred landscapes of Crete comprised not just court buildings, but also a host of other places and shrines, such as caves and peak sanctuaries, which lie outside the focus of this paper (Cherry 1986; Peatfield 1987; Watrous 1996; Tomkins 2009; 2011; Haggis 1999).

\section{Identifying the Main Sacred Venue}

The suggestion that the court buildings were primarily religious buildings and not palaces sensu stricto is certainly not a new one (Faure 1973; Melas 1995; Schoep 2002; Driessen 2002; Day and Wilson 2002; Pilali-Papasteriou 2004), but its incorporation into a broader spatial model for Minoan power relations represents a new departure. I argue here that the court buildings were the main religious venues in society from the Early Bronze Age (Hue and Pelon 1992; Pelon 2005; Tomkins and Schoep 2010; Tomkins 2011).

Beneath the floors of the EM III/MM IA court building at Malia were found the remains of an EM IIB building, similarly designed around a large open space broadly congruent with the central court of the later building (Pelon 2005). Although it has been claimed that the remains belong to 'scattered houses' (Watrous 1994), the common orientation of the walls is more indicative of a single building, an interpretation only strengthened by the fact that they share precisely the same orientation as the later court building and that, like the latter, the building comprised a large central court delimited by rooms to the north, west, and probably also east (see Schoep 2004a for references), and had an EM IIB portico on its west side in much the same way as its Middle Bronze Age successor (Pelon 1999).

At Knossos, a more complex and deep history of major terracing, levelling and construction episodes, stretching back to Final Neolithic (FN) IV, is beginning to emerge, within which long-known, but seemingly isolated early architectural units, such as the EM III Northwest Platform and the Early Keep now find greater context and meaning (Tomkins 2011). This work suggests that in the beginning (FN IV) ceremonial activity was focused on a large rectangular court below the present Central Court, and that the first of a series of court buildings or 'insulae' may have been in place as early as EM IIA (Tomkins 2011).

Recent work at Phaistos has established that the location of the later lower West Court was used as a venue for group feasting from the late FN, as suggested by deposits of tableware and animal bone (Todaro 2005; 2011; Di Tonto and Todaro 2008). The hill was reorganized in the course of two building projects that took place at the beginning of EM IIA, and again and more decisively at the beginning of EM III, leading to the creation of the terraces upon which the MM IB-II palace was later built (Todaro 2011). This coincides with a shift in the locus of habitation to the northernmost and southernmost slopes of the hill, which has been interpreted as a result of the establishment of the hilltop as a specialized place of ceremony.

From their inception, the court buildings appear to have served as venues for the ritualised 
consumption of food and drink by groups of differing size and composition, and this practice can be attested throughout their period of usage (Todaro 2011; Militello 2011; Tomkins 2011). In addition to broad continuities in practice, the early court buildings also exhibit continuity in form and orientation (Shaw 1977; Cherry 1986). Particularly notable is the way their location and orientation remained immutable, despite the fact that each of them saw modification and rebuilding on many occasions during the lifetime of their use, from EM II until LM IB (са. 2700-1490/1470 вс), in the case of Malia and perhaps Phaistos, or, in the case of Knossos, until LM IIIA2 (ca. 1375 BC). Outside Crete the extraordinary longevity of this spatial continuity only finds parallels in the context of buildings of a sacred, ceremonial character (Postgate 1992: 137).

In the Near East, only the temple remained in the same position through time because its location was sacrosanct, while specific rulers usually built a palace for themselves in a location of their choosing (Postgate 1992: 137). The construction of court buildings may now, thanks to recent work at Knossos and Phaistos, be properly understood (Todaro 2011; Schoep 2011; Tomkins 2011) as implying the appropriation of a locale previously imbued with significant meaning and thereby 'the timeless values which seemingly governed order in the world were increasingly mediated and therefore controlled by a certain group' (Barrett 1998: 255-56). Day and Wilson (2002: 148; see also Evans 1928: 2-3) have argued that the special status and even sanctity of the Kephala hill at Knossos may be due to its being perceived as the 'ancestral home of the original settlers of Crete'. While it no longer seems so likely that Knossos actually played such a prominent role in the peopling of Crete (Tomkins 2008), there can be little doubt that the creation and manipulation of traditions of place, identity and belonging during the late FN and Early Bronze Age played a major role in the legitimation of elite power strategies within and beyond Knossos (Tomkins 2011). A similar suggestion has been made for Phaistos, which perhaps came to be viewed as the place of origin for several settlements in the Mesara (Todaro 2003). Thus, as religious centres, the court buildings were more than just feasting arenas or communal centres; they were cult centres, tied in with specific belief systems and cosmologies (Schoep 2011). An example of the sort of cult paraphernalia that might be associated with these buildings is provided by the MM IA-B Vat Room Deposit at Knossos (MacGillivray 1997; Panagiotaki 1999: 275).

As religious centres, the court buildings should be expected to have had an important economic aspect (Militello 2011), without however implying that they were controlling the entire economy (Schoep 2010). Besides the storage of agricultural goods, there is evidence for the specialized production of goods such as textiles (Schoep 2010; Militello 2011) that may in the first place have been intended for consumption in these buildings. This is perhaps also suggested by the production debris from the Vat Room (Panagiotaki 1999: 275). It is equally clear, however, that not all material culture consumed in the court buildings was produced there. The pottery consumed in these buildings in the Middle Bronze Age was acquired from local and nonlocal workshops and reflects conscious choices on the part of the consumer (Day and Wilson 1998; Rethemniotakis and Christakis 2004).

The court buildings may have functioned in a similar way to the 'temples' of the Near East, in which case they may similarly have owned land and cultivated cereals, vegetables, and tree crops and practised animal husbandry (Postgate 1992: 114). It is interesting to note that the MM III Cretan Hieroglyphic tablets from Knossos document large numbers of livestock (Schoep 2004b: 288) and perhaps also the delivery of livestock and agricultural products (Karnava 2006: 64-66). Some form of redistribution may very well have formed part of the economy of these buildings (e.g. remuneration of staff, dispensing 
of foodstuffs to priests, gods, etc.) without implying that the economic system of the whole of Minoan society was organized on a redistributive basis (Halstead 1992; 2004; Cherry 1999).

There can be no doubt that the court buildings could not have been run without a central authority. The question is rather what form this authority took and where it resided. Elsewhere in the eastern Mediterranean, such authority can be situated along a political-sacred continuum that encompasses a variety of scenarios, from the combination of both in a single person (theocracy) to a distinction between a secular and a religious leader (Van De Mieroop 1997: 33). In addition, there were different degrees of interdependence between palace and temple. It is not clear at present where along this continuum the Cretan evidence fits-whether political and religious authority resided in one individual (as would be the case in a theocratic society), or in different individuals.

\section{Identifying the Seat(s) of Political Authority}

According to the alternative spatial model of power under exploration here the main seat of political authority is unlikely to have been the court building and should be sought elsewhere in the settlement or perhaps even the wider region. Unfortunately, this exercise is complicated by the fact that few settlements have been extensively excavated, and by the waxing and waning of high-profile buildings outside the court buildings.

I have argued elsewhere in the context of MM II Malia (Schoep 2002a; 2004; 2006; Figure 3) that several high-profile complexes (Quartier $\mathrm{Mu}$, Crypte Hypostyle, Magasins Dessenne, etc.) distinguish themselves from ordinary residences not only through their elaborate architecture or sheer size, but also by the practices that they hosted (i.e. innovative architecture, attached craft specialists, large-scale storage, expansion of the premises, use of writing and sealing, ceremonial practices, etc.). Moreover, the co-existence of these high-profile complexes would seem to suggest that political and economic power was not concentrated in the court building. The presence of innovative architectural features and elite practices in these highprofile buildings contrasts markedly with their comparative absence from the court building at this time, which has been noted as displaying 'archaic' features (Pelon 2005). The court building at Malia does not seem to participate in this urban landscape of intensive social, political, economic and even religious competition, a situation that fails to accord with the traditional Palace-Temple model, where such power is centralized in the court building (Schoep 2002; 2004). I have labelled this spatial pattern 'heterarchical' (Schoep 2002: 107), in order to highlight the horizontal diversity that is part of hierarchy and without the intention of implying that hierarchical relations were entirely lacking.

It is of course difficult to reconstruct the exact power relations between the groups inhabiting the high-profile complexes, but it seems likely in the case of Malia that there was a primus inter pares. Was this the household/s residing in Quartier Mu (Figure 4), as Poursat (2011) argues on the basis of their involvement in metalworking and overseas contacts? If so, its position may have been short-lived, perhaps restricted to MM II, when Quartier Mu greatly expanded (Poursat 2011), or even MM IIB only. Perhaps it is in the prominent position of Quartier $\mathrm{Mu}$ at the end of MM II that we should seek reason for its wholesale destruction and the subsequent abandonment of this area of the settlement for many future generations? In LM I Malia, House Epsilon seems to have been superior to other houses in the settlement, not only in terms of its size (3000 sq. m), but also with regard to its architectural elaboration, incorporating an impressive façade, a small court and a circular stone structure (kouloura) that is interpreted as a silo for grain (Bradfer-Burdet 2005). In this case, it would seem that between MM IIB and LM I the main venue of political authority, what would in the Near East be glossed as the 'palace', 


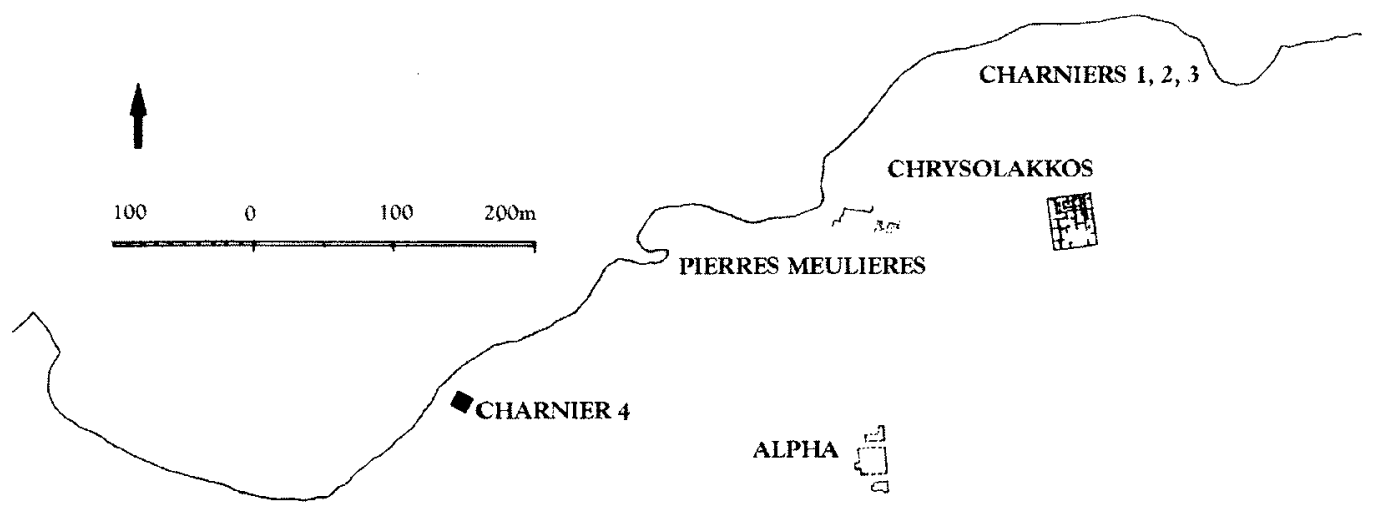

THITA

S ROMAN BASILICA

LOCATION GAMMA

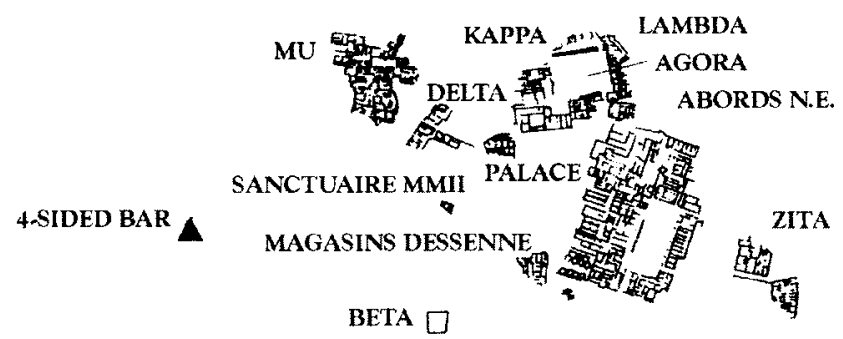

SANCTUAIRE AUX CORNES a

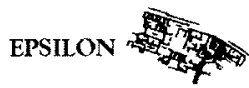

Figure 3. Plan of Malia (from Schoep 2002: 108, fig. 1).

might have shifted in location at least once, from Quartier Mu to Quartier Epsilon.

The model proposed here of spatial separation between the political and religious institutions is also applicable to other urban centres and periods other than the Middle Bronze Age. However, it seems likely that the balance of power will have varied within and between settlements and over time. Unlike Malia, which operated as the single pre-eminent centre in its region, other regions that are characterized by the co-existence of multiple centres, such as the western Mesara, north-central Crete and perhaps the Mirabello Bay, may reveal a more complicated picture. A detailed analysis of the function and biographies of the high-profile buildings in these regions, which exceeds the scope of the present paper, is needed to shed light on the matter.

Interestingly, spatial separation of the main venues of power has already been suggested for Neopalatial Knossos:

The grandest example [of the late independent houses outside the palace], called the 
Little Palace, together with the Unexplored Mansion, both incorporated architectural features and religious elements best known from the New Palace itself. The Little Palace may have been exactly that, namely a small palatial building for the ruling family to live in, either on the grounds of greater privacy or for reasons of Palace sanctity (Macdonald 2005: 91).

Was the Little Palace and Unexplored Mansion complex (Figure 5) truly exceptional in LM I Knossos (Figure 6) or should other potential seats of political authority, such as the building at Archanes, be considered? If the Little Palace is considered as the seat of a political authority, it is clear that the latter contained a very high component of cult rooms (Hatzaki 2005; Macdonald 2005), emphasising the potential ideological intertwinement of the sacred and the political.

In the western Mesara, multiple centres existed and the waxing and waning of high-profile buildings within them hints at a shifting, fluid landscape of power. The court building at Phaistos would appear to have been the main religious centre in EM and MM (Todaro 2011; Militello

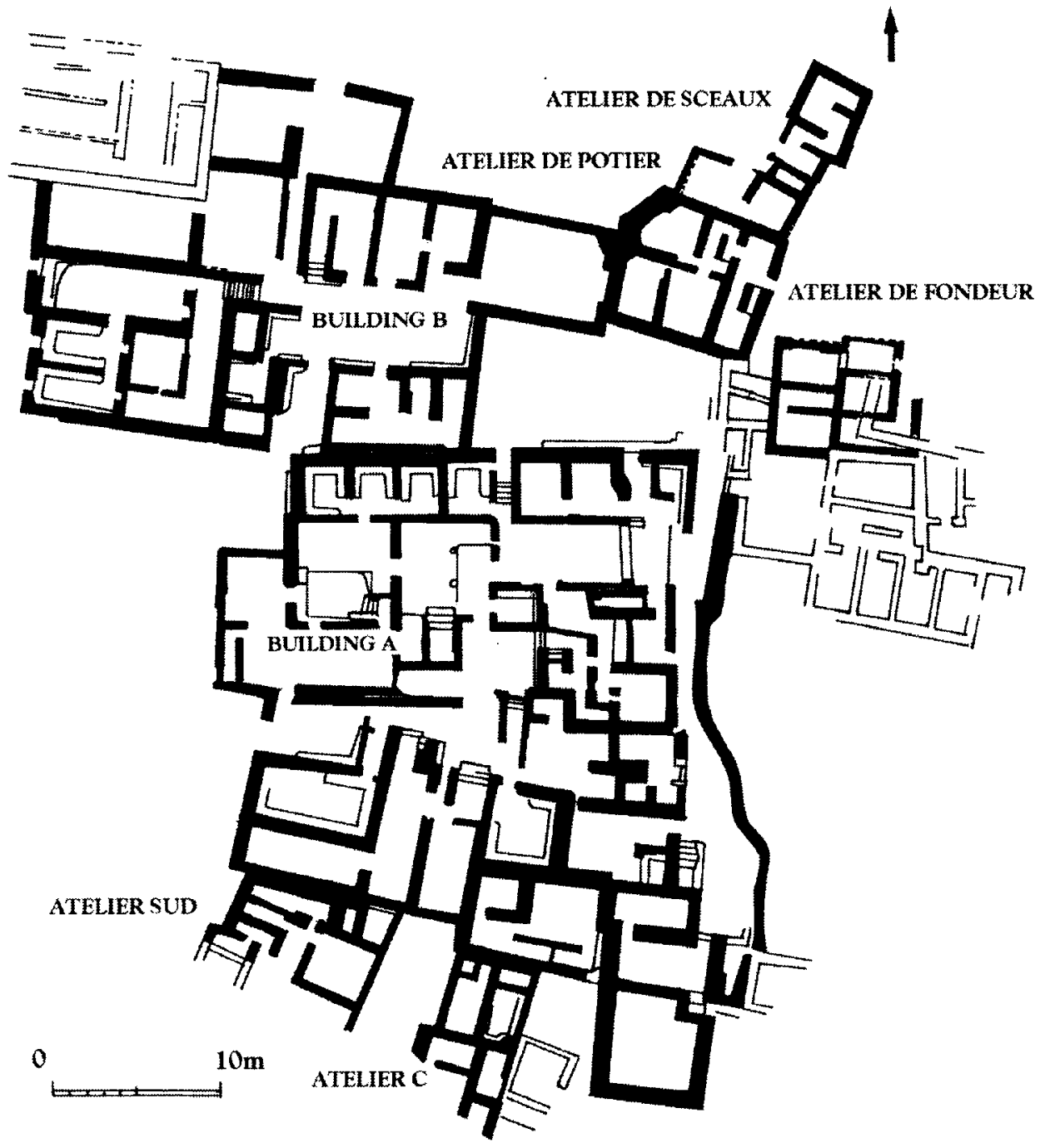

Figure 4. Plan of Quartier Mu, Malia (from Schoep 2002: 109, fig. 3). 
2011), while the main venue associated with political authority may have been either an (unexplored) building complex at Phaistos or elsewhere, such as Ayia Triada. Alternatively, there may have been multiple such venues of political authority at this time in the main population centres of the western Mesara. In the Neopalatial period, however, the fact that the court building at Phaistos was under construction for most of LM I may suggest that the main religious venue had shifted, perhaps to Ayia Triada. It is interesting to note that the cultic character of the 'villa' at Ayia Triada has recently been stressed (Puglisi 2003) over its economic and political function. If the 'villa' was the main religious institution, could the Casa Est be regarded as the place of political representation?

\section{Conclusion}

The traditional Palace-Temple model, which combines the political and the religious under one roof, owes more to Evans' particular views of Minoan society and his cultural and intellectual background than it does to the archaeological evidence that has accrued during the century since it was first formulated. It has been argued here that the Palace-Temple model is anomalous in the context of the wider east Mediterranean because in none of the major Bronze Age societies in the east Mediterranean is political and sacred authority ever concentrated in a single building. Even in theocratic societies, where a single person has religious and political power, the main political and sacred venues are

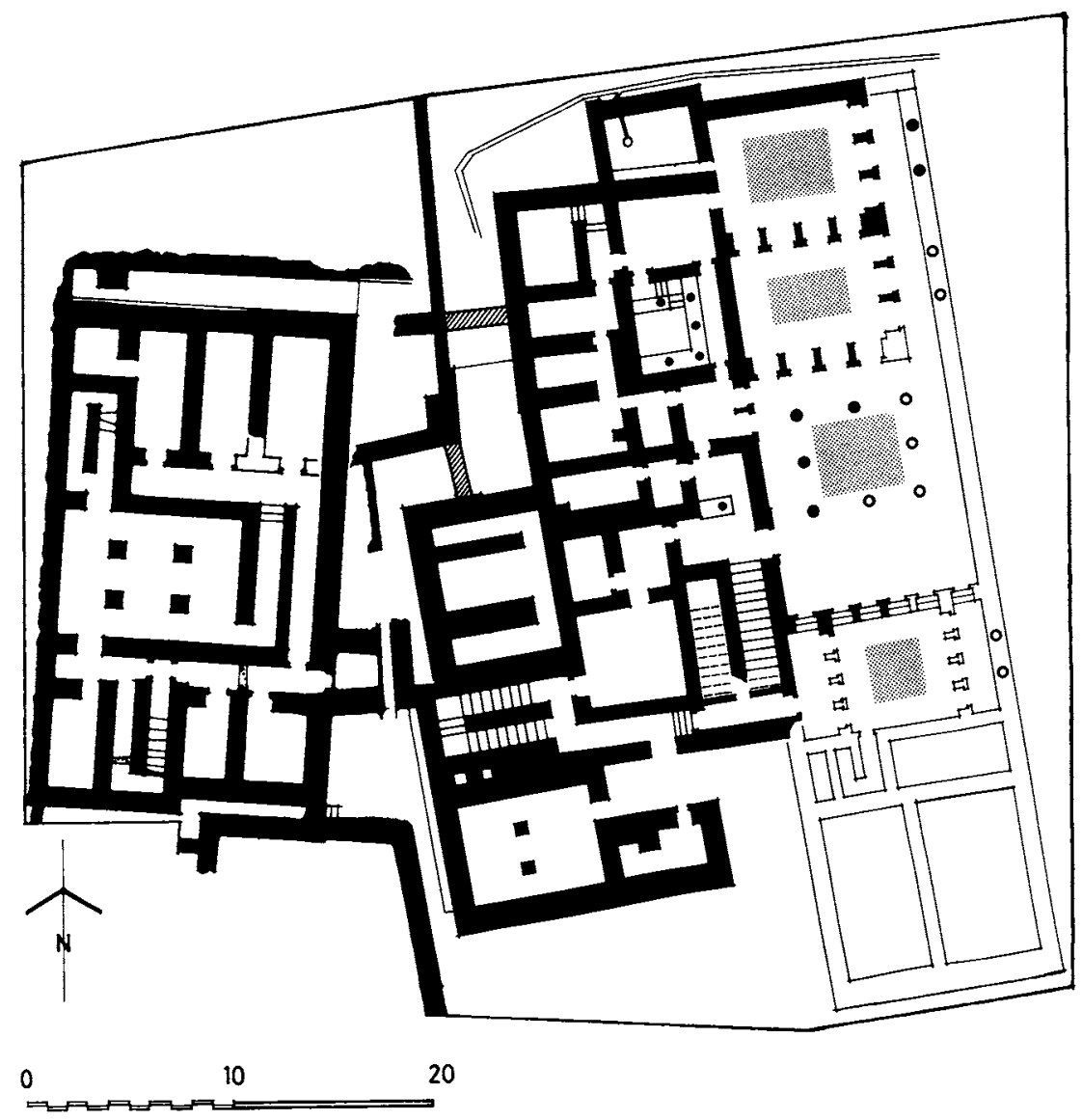

Figure 5. Plan of the Unexplored Mansion and the Little Palace (from Macdonald 2005). 


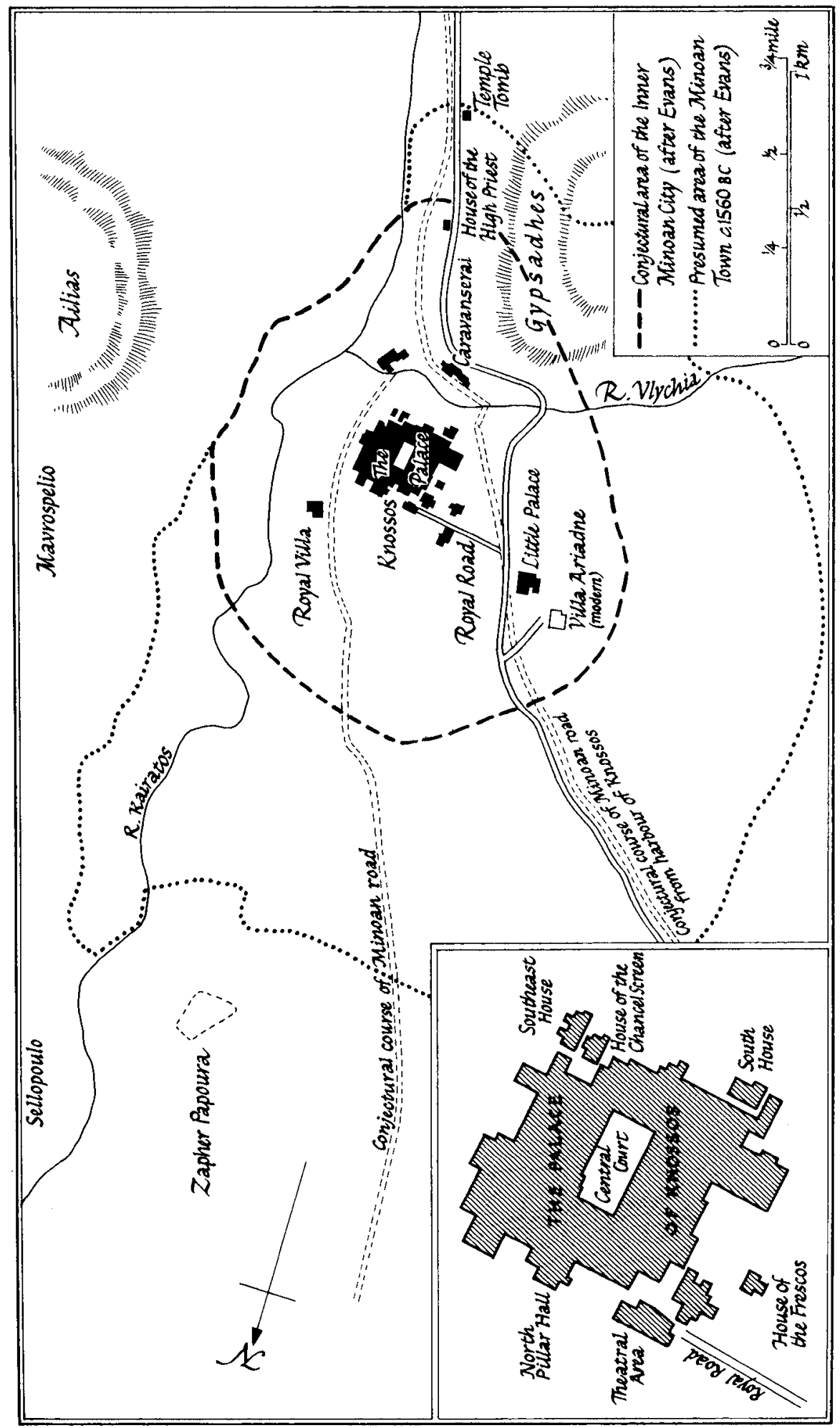


geographically separated. I have argued that one of the reasons why Evans' Palace-Temple model has enjoyed such longevity is a general underlying belief that Crete was different from other societies in the eastern Mediterranean. This belief in Cretan otherness can be traced back to Evans' own Creto-centrism, which artificially alienated Bronze Age Crete from its Asiatic neighbours and familiarized it for modern Europeans, in order to fit it more easily into a particular favoured narrative of the Cretan origins of European modernity.

The second point made in this paper is that a model in which the main political and sacred venues of power are located in different venues may actually more faithfully describe the Cretan Bronze Age data. There is sufficient evidence to suggest that court buildings functioned as the main religious centres (or 'temples', without implying that court buildings were identical to Near Eastern temples), at least within the island's principal urban centres; while there are sufficient indications from the admittedly still under-explored urban landscapes to suggest that the main seat of political power (or 'palaces', in the Near Eastern sense) were actually located outside the court buildings.

While this alternative model offers new and exciting avenues, however, there are important aspects that could not be examined in the present paper. The present paper has discussed the validity of the model for the Middle and Late Bronze Age, but the situation in the Early Bronze Age would repay further examination. An evolution seems to take place from a situation in the Early Bronze Age where the court buildings functioned as the main venues for cult and social reproduction, to one in MM I-II (and MM III-LM I), where aspects of this function came to be increasingly appropriated by high-profile elite structures within their surrounding urban settlements (Schoep 2011). This may represent a significant development, comparable to the rise of a secular authority in the Near East in the mid-third millennium, at which point the temples, which had been politically and economically dominant, now coexisted in the urban landscape with the palace (Van de Mieroop 1997: 16).

\section{About the Author}

The author is a lecturer at the University of Leuven (Belgium) and co-director of the Belgian excavations at Sissi (Crete). Her research interests include the Minoan palaces and their role in society, administration and writing, funerary practices and social and political organization.

\section{References}

Adams, E.

2006 Social strategies and spatial dynamics in Neopalatial Crete: an analysis of the north-central area. American Journal of Archaeology 110: 1-36.

Ahlström, G.W.

1995 Administration of the state in Canaan and ancient Israël. In J.M. Sasson (ed.), Civilizations of the Ancient Near East, 529-43. New York: Scribner.

Akkermans, P.M.M.G., and G.M. Schwartz

2003 The Archaeology of Syria: From Complex Huntergatherers to Early Urban Societies (ca. 16000300 BC). Cambridge: CUP.

Arnold, D.

2002 The royal palace: architecture, decoration and furnishings. In C. Ziegler and F. Tiradritti (eds.), Pharaohs : Exposition au Palazzo Grassi à Venise, 271-98. London: Thames and Hudson.

Baines, J.

1995 Palaces and temples of ancient Egypt. In J.M. Sasson (ed.), Civilizations of the Ancient Near East, 303-317. New York: Scribner.

Barratt, J.C.

1998 The mythical landscapes of the British Iron Age. In W. Ashmore and A.B. Knapp (eds.), Archaeologies of Landscapes: Contemporary Perspectives, 253-65. Oxford: Blackwell.

Beckman, G.

1995 Royal ideology and state administration in Hittite Anatolia. In J.M. Sasson (ed.), Civilizations of the Ancient Near East, 529-43. New York: 
Scribner.

Bennett, E.L.

1961-62 On the use and misuse of the term 'priest-king'. Kretika Chronika 15-16: 327-35.

Betancourt, P.P.

2007 Introduction to Aegean Art. Philadelphia: INSTAP Academic Press

Bintliff, J.L.

1984 Structuralism and myth in Minoan studies. Antiquity 58: 33-38.

Bradfer-Burdet, I.

2005 Une kouloura dans le 'Petit Palais' de Malia. In I. Bradfer-Burdet, B. Detournay and R. Laffineur (eds.), KRHS TEXNITHS: L'artisan crétois. Aegaeum 26: 39-50. Liège/Austin: Service de l'histoire de l'art et d'archéologie de la Grèce antique (Liège) and Program in Aegean Scripts and Prehistory, The University of Texas at Austin.

Blakholmer, F.

2006 The arts of Bronze Age Crete and the European modern style: reflecting and shaping different identities. In Y. Hamilakis and N. Momigliano (eds.), Archaeology and European Modernity: Producing and Consuming the 'Minoans'. Creta Antica 7: 219-40. Padova: Aldo Ausilio.

Branigan, $\mathrm{K}$.

1987 The economic role of the first palaces. In R. Hägg and N. Marinatos (eds.), The Function of the Minoan Palaces. Skrifter Utgivna av Svenska Institutet I Athen, $4^{\circ}$ 35: 245-49. Stockholm: Paul Åström's Förlag.

1988 Some observations on state formation in Crete. In E. French and K. Wardle (eds.), Problems in Greek Prehistory: Papers Presented at the Centenary Conference of the British School of Archaeology at Athens, Manchester, April 1986, 63-71. Bristol: Bristol Classical Press.

1989 Minoan foreign relations in transition. In R. Laffineur (ed.), Le Monde égéen du Bronze Moyen au Bronze Récent, 65-71. Aegaeum 3. Liège: Université de Liège. Histoire de l'art et archéologie de la Grèce antique Liège.

Broodbank, C.

2000 An Island Archaeology of the Early Cyclades. Cambridge: Cambridge University Press.

Charbonneaux, J.

1929 L'art égéen. Bibliothèque de l'histoire de l'art. Paris: van Oest.
Cherry, J.F.

1984 The emergence of the state in the prehistoric Aegean. Proceedings of the Cambridge Philological Society 210: 18-48.

1986 Polities and palaces: some problems in Minoan state formation. In C. Renfrew and J.F. Cherry (eds.), Peer Polity Interaction and Socio-Political Change, 19-45. Cambridge: Cambridge University Press.

1999 Social development, management of production, and symbolic representation in Prepalatial Crete. In A. Chaniotis (ed.), From Minoan Farmers to Roman Traders: Sidelights on the Economy of Ancient Crete. Heidelberger Althistorische Beiträge und Epigraphische Studien 25: 17-23. Stuttgart: Franz Steiner Verlag.

Coulomb, J.

1979 Le prince aux lis de Knossos reconsidéré. Bulletin de Correspondance Hellénique 103: 29-50.

Darcque, P., M. Fotiadis, and O. Polychronopoulou (eds.)

2006 Mythos: La prébistoire égéenne du XIX $X^{e}$ au XXI siècle après J.-C. Actes de la table ronde internationale d'Athènes (21-22 novembre 2002). Bulletin de Correspondance Hellénique Supplément 46. Paris: De Boccard.

Day, P.M., and D.E. Wilson

1998 Consuming power: Kamares ware in Protopalatial Knossos. Antiquity 72: 350-58.

2002 Landscapes of memory, craft and power in Prepalatial and Protopalatial Knossos. In Y. Hamilakis (ed.), Labyrinth Revisited: Rethinking Minoan Archaeology, 143-66. Oxford: Oxbow.

De Miroschedji, P.

1999 Yarmuth: the dawn of city-states in southern Canaan. Near Eastern Archaeology 62: 2-19.

Di Tonto, S., and S. Todaro

2008 The Neolithic settlement of Phaistos revisited: evidence for ceremonial activity on the eve of the Bronze Age. In V. Isaakidou and P. Tomkins (eds.), Escaping the Labyrinth: New Perspectives on the Neolithic of Crete. Sheffield Studies in Aegean Archaeology 8: 177-90. Oxford: Oxbow.

Dickinson, O.T.P.K.

1994a The Aegean Bronze Age. Cambridge: Cambridge University Press

$1994 \mathrm{~b}$ Comments on a popular model of Minoan religion. Oxford Journal of Archaeology 13: 173-84.

Driessen, J. 
2001 Crisis cults on Minoan Crete? In R. Laffineur and R. Hägg (eds.), POTNIA: Deities and Religion in the Aegean Bronze Age. Proceedings of the 8th International Aegean Conference, Göteborg University, 12-15 April 2000. Aegaeum 22: 361-69. Liège/Austin: Service de l'histoire de l'art et d'archéologie de la Grèce antique (Liège) and Program in Aegean Scripts and Prehistory, The University of Texas at Austin.

2002 The king must die. In J. Driessen, I. Schoep and R. Laffineur (eds.), Monuments of Minos: Rethinking the Minoan Palaces. Proceedings of the International Workshop 'Crete of the Hundred Palaces?' held at Université Catholique de Louvain, Louvain-la-Neuve, 14-15 December 2001. Aegaeum 23: 1-14. Liège/Austin: Service de l'histoire de l'art et d'archéologie de la Grèce antique (Liège) and Program in Aegean Scripts and Prehistory, The University of Texas at Austin.

Evans, A.J.

1901 Mycenaean Tree and Pillar Cult. London: Macmillan.

1921 The Palace of Minos. Vol. I. London: Macmillan.

1928 The Palace of Minos. Vol. II. London: Macmillan.

1935 The Palace of Minos. Vol. IV. London: Macmillan.

2008 [1877] Illyrian Letters: A Revised Selection of Correspondence from the Illyrian Provinces of Bosnia, Herzegovina, Montenegro, Albania, Dalmatia, Croatia, and Slavonia. Addressed to the 'Manchester Guardian' during the year 1877. New York: Cosimo.

Farnoux, A.

1993 Cnossos ou l'archéologie d'un rêve. Paris: Gallimard.

1995 La fondation de la royauté minoenne: XXème siècle avant ou après jésus-christ? In R. Laffineur and W.-D. Niemeier (eds.), Politeia: Society and State in the Aegean Bronze Age. Proceedings of the 5th International Aegean Conference, University of Heidelberg, Archäologisches Institut, 10-13 April 1994. Aegaeum 12: 323-33. Liège/Austin: Service de l'histoire de l'art et d'archéologie de la Grèce antique (Liège) and Program in Aegean Scripts and Prehistory, The University of Texas at Austin.

Faure, P.
1973 La vie quotidienne en Crète au temps de Minos. Paris: Hachette.

Feldman, M.H.

2006 Diplomacy by Design: Luxury Arts and an International Style' in the Ancient Near East, 1400 1200 BCE. Chicago: Chicago University Press.

Finley, M.I.

1957 The Mycenaean tablets and economic history. Economic History Review 10: 128-41.

Galaty, M.

2008 Review of J.J. Christie and P.J. Sarro (eds.), Palaces and Power in the Americas: From Peru to the Northwest Coast (Austin, TX: University of Texas Press, 2006). Cambridge Archaeological Journal 18: 428-31.

Garstang, J.

1929 The Hittite Empire: Being a Survey of the History, Geography and Monuments of Hittite Asia Minor and Syria. London: Constable.

Gere, C.

2009 Knossos and the Prophets of Modernism. Chicago: University of Chicago Press.

Gesell, G.

1983 The place of the goddess in Minoan religion. In O. Krzyszkowska and L. Nixon (eds.), Minoan Society, 93-99. Bristol: Bristol Classical Press.

Haggis, D.C.

1999 Staple finance, peak sanctuaries, and economic complexity in late Prepalatial Crete. In A. Chaniotis (ed.), From Minoan Farmers to Roman Traders. Sidelights on the Economy of Ancient Crete. Heidelberger Althistorische Beiträge und Epigraphische Studien 25: 53-85. Stuttgart: Franz Steiner.

Halstead, P.

1981 From determinism to uncertainty: social storage and the rise of the Minoan palace. In A. Sheridan and G. Bailey (eds.), Economic Archaeology: Toward an Integration of Ecological and Social Approaches. British Archaeological Reports 96: 187-213. Oxford: British Archaeological Reports.

1988 On redistribution and the origin of the MinoanMycenaean palatial economies. In E.B. French and K.A. Wardle (eds.), Problems in Greek Prehistory: Papers Presented at the Centenary Conference of the British School of Archaeology, Manchester April 1986, 519-30. Bristol: Bristol Classical Press. 
1992 The Mycenaean palatial economy: making the most of the gaps in the evidence. Proceedings of the Cambridge Philological Society: 57-86.

2004 Life after Mediterranean polyculture: the subsistence subsystem and the emergence of civilisation revisited. In J.C. Barrett and P. Halstead (eds.), The Emergence of Civilisation Revisited. Sheffield Studies in Aegean Archaeology 6: 189206. Oxford: Oxbow.

Halstead, P., and J. O'Shea

1982 A friend in need is a friend indeed: social storage and the origins of social ranking. In C. Renfrew and S. Shennan (eds.), Ranking, Resource and Exchange: Aspects of the Archaeology of Early European Society, 92-99. Cambridge: Cambridge University Press.

Hamilakis, Y.

2002a Too many chiefs? Factional competition in Neopalatial Crete. In J. Driessen, I. Schoep and R. Laffineur (eds.), Monuments of Minos: Rethinking the Minoan Palaces. Proceedings of the International Workshop 'Crete of the Hundred Palaces?' held at Université Catholique de Louvain, Louvain-la-Neuve, 14-15 December 2001. Aegaeum 23: 179-99. Liège/Austin: Service de l'histoire de l'art et d'archéologie de la Grèce antique (Liège) and Program in Aegean Scripts and Prehistory, The University of Texas at Austin.

2002b What future for the Minoan past? Rethinking Minoan archaeology. In Y. Hamilakis (ed.), Labyrinth Revisited: Rethinking Minoan Archaeology, 2-29. Oxford: Oxbow.

Hamilakis, Y., and N. Momigliano (eds.)

2006 Archaeology and European Modernity: Producing and Consuming the 'Minoans'. Creta Antica 7. Padova: Aldo Ausilio.

Hatzaki, E.

2005 Knossos: The Little Palace. British School at Athens Studies 38. London: British School at Athens.

Higgins, R.

1967 Minoan and Mycenaean Art. London: Thames and Hudson.

Hitchcock, L., and P. Koudounaris

2002 Virtual discourse: Arthur Evans and the reconstructions of the Minoan palace at Knossos. In Y. Hamilakis (ed.), Labyrinth Revisited: Rethinking Minoan Archaeology, 40-58. Oxford:
Oxbow.

Hood, S.

1978 The Arts of Prehistoric Greece. London: Richard Clay.

1995 The Minoan palace as residence of gods and men. In N.E. Papadogiannakis (ed.), Proceedings of the Seventh International Cretological Congress, Vol. A1, 393-407. Rethymnon: Historical Society of Crete.

Hue, M., and O. Pelon

1992 La salle à piliers du palais de Malia et ses antécédents. Bulletin de Correspondance Hellénique 116: 1-36.

Hutchinson, R.W.

1962 Prehistoric Crete. London: Cox and Wyman.

Karnava, A.

2006 Indications of Minoan fiscal registrations. In M. Perna (ed.), Fiscality in Mycenaean and Near Eastern Archives. Proceedings of the Conference held at Soprintendenza Archivistica per la Campania, Naples, 21-23 October 2004. Studi Egei e Vicinorientali 3: 359-68. Paris: De Boccard.

Kemp, B.

2006 Ancient Egypt: Anatomy of a Civilization. London: Routledge.

Knappett, C.J.

1999 Assessing a polity in Protopalatial Crete: the Malia-Lasithi state. American Journal of Archaeology 103: 615-39.

2009 Scaling up: from household to state in Bronze Age Crete. In S. Owen and L. Preston (eds.), Inside the City in the Greek World: Studies of Urbanism from the Bronze Age to the Hellenistic Period, 14-26. Oxford: Oxbow.

Lapatin, K.

2002 Mysteries of the Snake Goddess: Art, Desire, and the Forging of History. Cambridge, MA: Da Capo.

Lewthwaite, J.

1983 Why did civilisation not emerge more often? A comparative approach to the development of Minoan Crete. In O. Krzyszkowska and L. Nixon (eds.), Minoan Society, 171-84. Bristol: Bristol Classical Press.

Lloyd, S., and J. Mellaart

1965 Beycesultan, Vol. II: Middle Bronze Age Architecture and Pottery. London: British Institute of Archaeology at Ankara.

Macdonald, C.F. 
2005 Knossos. London: The Folio Society.

Macdonald, C.F., and C.J. Knappett

2007 Knossos: Protopalatial Deposits in Early Magazine $A$ and the South-west Houses. British School at Athens Supplementary Volume 41. London: British School at Athens.

MacGillivray, J.A.

1994 The early history of the Palace at Knossos (MM I-II). In D. Evely, H. Hughes-Brock, and N. Momigliano (eds.), Knossos: A Labyrinth of History. Papers Presented in Honour of Sinclair Hood, 45-55. Oxford: Oxbow, for the British School at Athens.

1997 Knossos: Pottery Groups of the Old Palace Period. British School of Athens Studies 5. London: British School at Athens.

2001 Minotaur: Sir Arthur Evans and the Archaeology of the Minoan Myth. London: Pimlico.

Manning, S.W.

1993 The emergence of divergence: development and decline on Bronze Age Crete and the Cyclades. In C. Mathers and S. Stoddart (eds.), Development and Decline in the Mediterranean Bronze Age. Sheffield Archaeological Monographs 8: 221-70. Sheffield: J.R. Collis Publications.

2008 Formation of the palaces. In C. Shelmerdine (ed.), The Cambridge Companion to the Aegean Bronze Age, 105-20. Cambridge: Cambridge University Press.

Margueron, J.-C.

1995 Mari: a portrait of a Mesopotamian city-state. In J.M. Sasson (ed.), Civilizations of the Ancient Near East, 885-900. New York: Scribner.

Marinatos, N.

1993 Minoan Religion: Ritual, Image and Symbol. Columbia, SC: University of South Carolina Press.

2007 The lily crown and sacred kingship in Minoan Crete. In P.P. Betancourt, M.C. Nelson and $H$. Williams (eds.), Krinoi kai Limenes: Studies in Honor of Joseph and Maria Shaw, 271-76. Philadelphia: INSTAP Academic Press.

McEnroe, J.C.

1995 Sir Arthur Evans and Edwardian archaeology. Classical Bulletin 71: 3-18.

2002 Cretan questions: politics and archaeology 1898-1913. In Y. Hamilakis (ed.), Labyrinth Revisited: Rethinking Minoan Archaeology, 59-72. Oxford: Oxbow.
Melas, M.

1995 Transcending the 'palace': kinship versus kingship, and the social dimension of Minoan ritual. In N.E. Papadogiannakis (ed.), Proceedings of the Seventh International Cretological Congress, Vol. A2, 613-24. Rethymnon: Historical Society of Crete.

Milano, L.

1995 Ebla: a third-millennium city-state in ancient Syria. In J.M. Sasson (ed.), Civilizations of the Ancient Near East, 1219-30. New York: Scribner.

Militello, P.

2011 Emerging authority: a functional analysis of the MM II settlement of Festòs. In I. Schoep, P. Tomkins and J. Driessen (eds.), Back to the Beginning: Reassessing Social, Economic and Political Complexity in the Early and Middle Bronze Age on Crete. Oxford: Oxbow (in press).

Momigliano, $\mathrm{N}$.

2006 Sir Arthur Evans, Greek myths, and the Minoans. In P. Darcque, M. Fotiadis and O. Polychronopoulou (eds.), Mythos: La préhistoire égéenne du XIXe au XXIe siècle après J.-C. Actes de la table ronde internationale d'Athènes (21-22 novembre 2002). Bulletin de Correspondance Hellénique Supplément 46 : 73-80. Paris: De Boccard.

Morris, C.

2006 From ideologies of motherhood to 'collecting mother goddesses'. In Y. Hamilakis and N. Momigliano (eds.), Archaeology and European Modernity: Producing and Consuming the 'Minoans'. Creta Antica 7: 69-78. Padova: Aldo Ausilio.

Moser, S.

2001 Archaeological representation: the visual conventions for constructing knowledge about the past. In I. Hodder (ed.), Archaeological Theory Today, 262-83. Cambridge: Polity.

Neve, P.

1993 Hattusa : Stadt der Götter und Tempel. Neue Ausgrabungen in der Hauptstadt der Hethiter. Mainz: von Zabern.

Niemeier, W.-D.

1988 The 'priest-king' fresco from Knossos: a new reconstruction and interpretation. In E.B. French and K.A. Wardle (eds.), Problems in Greek Prehistory: Papers Presented at the Cente- 
nary Conference of the British School of Archaeology, Manchester April 1986, 235-44. Bristol: Bristol Classical Press.

O'Connor, D.

1993 The social and economic organization of ancient Egyptian temples. In J.M. Sasson (ed.), Civilizations of the Ancient Near East, 319-29. New York: Scribner.

Panagiotaki, M.

1999 The Central Palace Sanctuary at Knossos. BSA Supplementary Volume 31. London: British School at Athens.

Papadopoulos, J.

2005 Inventing the Minoans: archaeology, modernity and the quest for European identity. Journal of Mediterranean Archaeology 18: 87-149.

Peatfield, A.

1987 Palace and peak: the political and religious relationship between palaces and peak sanctuaries. In R. Hägg and N. Marinatos (eds.), The Function of the Minoan Palaces. Skrifter Utgivna av Svenska Institutet I Athen, $4^{\circ}$ 35: 89-93. Stockholm: Paul Åström's Förlag.

Pelon, O.

1997 Le système palatial minoen. Les Dossiers d'archéologie 222: 44-51.

1999 Travaux de l'école Française à Athènes. Malia: Le palais. Bulletin de Correspondance Hellénique 123: 468-81.

2005 Les deux destructions du palais de Malia. In I. Bradfer-Burdet, B. Detournay and R. Laffineur (eds.), KRHS TEXNITHS: L'artisan crétois. Aegaeum 26 : 185-98. Liège/Austin: Service de l'histoire de l'art et d'archéologie de la Grèce antique (Liège) and Program in Aegean Scripts and Prehistory, The University of Texas at Austin.

Pilali-Papasteriou, A.

2004 Knosos kai theokratia. In G. Cadogan, E. Hatzaki and A. Vasilakis (eds.), Knossos: Palace, City, State. British School at Athens Studies 12: 323-27. London: British School at Athens.

Pinnock, F.

2001 The urban landscape of old Syrian Ebla. Journal of Cuneiform Studies 53: 13-33.

Platon, N.

1983 The Minoan palaces: centres of organisation of a theocratic, social and political system. In O. Krzyszkowska and L. Nixon (eds.), Minoan
Society, 273-80. Bristol: Bristol Classical Press.

Postgate, N.

1992 Early Mesopotamia: Society and Economy at the Dawn of History. London: Routledge.

Poursat, J.-C.

2011 The emergence of elite groups at Protopalatial Malia: a biography of Quartier Mu. In I. Schoep, P. Tomkins and J. Driessen (eds.), Back to the Beginning. Reassessing Social, Economic and Political Complexity in the Early and Middle Bronze Age on Crete. Oxford: Oxbow (in press).

Preziosi, D.

2002 Archaeology as museology: re-thinking the Minoan past. In Y. Hamilakis (ed.), Labyrinth Revisited: Rethinking Minoan Archaeology, 30-39. Oxford: Oxbow.

Preziosi, D., and L. Hitchcock

1999 Aegean Art and Architecture. Oxford: Oxford University Press.

Puglisi, D.

2003 Il bastione Tardo Minoico I ad Haghia Triada: nuove osservazioni su cronologia e funzione. ASAtene 81(2): 73-93.

Renfrew, C.

1972 The Emergence of Civilisation: The Cyclades and the Aegean in the 3rd Millennium BC. London: Methuen.

Rethemniotakis, G., and C. Christakis

2004 Cultural interaction between Knossos and Pediada: the evidence from the Middle Minoan IB pottery. In G. Cadogan, E. Hatzaki and A. Vasilakis (eds.), Knossos: Palace, City, State. British School at Athens Studies 12: 169-76. London: British School at Athens.

Robertson, J.F.

1995 The social and economic organization of ancient Mesopotamian temples. In J.M. Sasson (ed.), Civilizations of the Ancient Near East, 44354. New York: Scribner.

Runnels, C., and P. Murray

2001 Greece before History: An Archaeological Companion and Guide. Stanford: Stanford University Press.

Sallaberger, W.

2007 The palace and the temple in Babylonia. In G. Leick (ed.), The Babylonian World, 265-75. London: Routledge.

Schoep, I.

2002 Social and political organization on Crete in 
the Proto-palatial period: the case of Middle Minoan II Malia. Journal of Mediterranean Archaeology 15: 101-132.

2004a Assessing the role of architecture in conspicuous consumption in the Middle Minoan I-II periods. Oxford Journal of Archaeology 23: 243-69.

2004b The socio-economic context of seal-use and administration at Knossos. In G. Cadogan, E. Hatzaki and A. Vasilakis (eds.), Knossos: Palace, City, State. British School at Athens Studies 12: 283-94. London: British School at Athens.

2006 Looking beyond the first palaces: elites and the agency of power in EM II-MM II Crete. American Journal of Archaeology 110: 37-64.

2009 Social and political aspects of urbanism in MM I-II Crete: towards a regional approach. In S. Owen and L. Preston (eds.), Inside the Greek City: Studies in Urbanism in the Greek World from the Bronze Age to the Hellenistic Period, 27-40. Oxford: Oxbow.

2010 Making elites: political economy and elite culture(s) in Middle Minoan Crete. In D. Pullen (ed.) Political Economies of the Aegean Bronze Age: Papers from the Langford Conference, Florida State University, Tallahassee, 22-24 February 2007, 66-85. Oxford: Oxbow.

2011 Bridging the divide between the Prepalatial and the Protopalatial period. In I. Schoep, P. Tomkins and J. Driessen (eds.), Back to the Beginning Reassessing Social, Economic and Political Complexity in the Early and Middle Bronze Age on Crete. Oxford: Oxbow (in press).

Shaw, J.

1977 The orientation of Minoan palaces. In G. Carratelli and G. Rizza (eds.), Antichità cretesi: Studi in onore di Doro Levi II. Cronache di Archaeologia 12-13: 47-59. Catania: University Press.

Shaw, M.

2004 The priest-king fresco from Knossos: man, woman, priest, king or someone else? In A. Chapin (ed.), Charis: Essays in Honor of S.A. Immerwahr. Hesperia Supplement 33: 65-84. Princeton: The American School of Classical Studies at Athens.

Sherratt, S.

2000 Arthur Evans, Knossos and the Priest-King. Oxford: Ashmolean Museum Publications.

2005 Arthur Evans and the first of the priest-kings. In A. Dakouri-Hild and S. Sherratt (eds.),
AUTHOCHTHON: Papers Presented to O.T.P.K. Dickinson on the Occasion of his Retirement. British Archaeological Reports International Series 1432: 229-41. Oxford: Archaeopress.

Strasser, T.

1997 Storage and states on prehistoric Crete: the function of the koulouras in the first Minoan palaces. Journal of Mediterranean Archaeology 10: 73-100.

Todaro, S.

2003 Haghia Triada nel period Antico Minoico. Creta Antica 4: 59-94.

2005 EM I-MM IA ceramic groups at Phaistos: towards the definition of a Prepalatial ceramic period. Creta Antica 6: 11-46.

2011 Craft production and social practice at Prepalatial Phaistos: the background to the first 'palace'. In I. Schoep, P. Tomkins and J. Driessen (eds.), Back to the Beginning: Reassessing Social, Economic and Political Complexity in the Early and Middle Bronze Age on Crete. Oxford: Oxbow (in press).

Tomkins, P.

2008 Time, space and the reinvention of the Cretan Neolithic. In V. Isaakidou and P. Tomkins (eds.), Escaping the Labyrinth: The Cretan Neolithic in Context. Sheffield Studies in Aegean Archaeology 8: 21-48. Oxford: Oxbow.

2009 Domesticity by default: ritual, ritualisation and cave-use in the Neolithic Aegean. Oxford Journal of Archaeology 128: 125-53.

2011 Behind the horizon: reconsidering the genesis and function of the 'first palace' at Knossos (Final Neolithic IV to Middle Minoan II). In I. Schoep, P. Tomkins and J. Driessen (eds.), Back to the Beginning. Reassessing Social, Economic and Political Complexity in the Early and Middle Bronze Age on Crete. Oxford: Oxbow (in press).

Tomkins, P., and I. Schoep

2010 Early Bronze Age: Crete. In E. Cline (ed.), The Oxford Handbook of the Bronze Age Aegean, 66-82. Oxford: Oxford University Press.

Traunecker, C.

2002 Pharaon ritualiste: le culte divin. In C. Ziegler and F. Tiradritti (eds.), Pharaohs: Exposition au Palazzo Grassi à Venise, 145-57. London: Thames and Hudson.

Treuil, R., P. Darcque, J.-Cl. Poursat, G. Touchais, L. Godart and J.-P. Olivier 
2008 Les civilizations egéennes du Neolithique et de l'Age du Bronze. Paris: Presses Universitaires de France.

Trigger, B., B.J. Kemp, D. O'Connor, and A.B. Lloyd

1983 Ancient Egypt: A Social History. Cambridge: Cambridge University Press,

Watrous, V.L.

1987 The role of the Near East in the rise of the Cretan palaces. In R. Hägg and N. Marinatos (eds.), The Function of the Minoan Palaces. Skrifter Utgivna av Svenska Institutet I Athen, $4^{\circ} 35$ : 65-70. Stockholm: Paul Åström’s Förlag.

1994 Review of Aegean prehistory, III: Crete from earliest prehistory through the Protopalatial period. American Journal of Archaeology 98: 695-753.
1996 The Cave Sanctuary of Zeus at Psychro: A Study of Extra-urban Sanctuaries in Minoan and Early Iron-Age Crete. Aegaeum 15. Liège/Austin: Service de l'histoire de l'art et d'archéologie de la Grèce antique (Liège) and Program in Aegean Scripts and Prehistory, The University of Texas at Austin.

Warren, P.

1975 The Aegean Civilizations: The Making of the Past. London: Elsevier-Phaidon.

1985 Minoan palaces. Scientific American 253: 94-103.

1987 The genesis of the Minoan palace. In R. Hagg and N. Marinatos (eds.), The Function of the Minoan Palaces. Skrifter Utgivna av Svenska Institutet I Athen, $4^{\circ}$ 35: 47-56. Stockholm: Paul Åström’s Förlag. 